\title{
Centenary Celebrations of the University of London
}

$\mathrm{T}$

HE hundredth anniversary of the University of London was celebrated during the week June 29 July 3 with a full programme of functions. The proceedings were inaugurated at an afternoon reception on Monday, June 29, in the Great Hall of the University at South Kensington. Here nearly two hundred representatives of universities and learned societies in every corner of the globe assembled to present addresses of congratulation and goodwill. The Chancellor, Lord Athlone, in welcoming the delegates, said that this great convention was a healthy reminder that learning recognized no national frontiers, that the whole band of great teachers, the whole band of eager students, were truly citizens of the wide world, and their influence for good was incalculable and illimitable. Honorary degrees were conferred on the following distinguished men, who were presented by the Public Orator: The Archbishop of Westminster, Dr. J. W. Mackail, Sir Charles Peers, Prof. G. M. Trevelyan, Mr. H. G. Wells, Senor Don Ramon Perez de Ayala (Doctors of Literature); Mr. S. A. Courtauld, Mr. P. M. Evans, Sir Joseph Larmor, Sir George Newman, Lord Snell, Lord Wright (Doctors of Law); Dr. R. Vaughan Williams (Doctor of Music); and Sir William Bragg and Prof. Max Planck (Doctors of Science). Degrees were also conferred in absentia on Dr. Emile Legouis (Doctor of Literature); Mr. Justice Cardozo (Doctor of Laws); Prof. Albert Einstein and Prof. Johan Hjort (Doctors of Science).

In the evening of the same day, a dinner was held at Grosvenor House. The Chancellor, who presided, read a message from His Majesty the King, Visitor of the University, conveying his sincere eongratulations to the University on the occasion of its centenary, and alluding to the progress of the new buildings at Bloomsbury as marking the beginning of a new era as well as a new century in the life of the University. Sir Thomas Inskip, in proposing the toast of "The University", said that within the space of a hundred years the University had attained such a position that it was able in everything but antiquity and beauty of situation to challenge the supremacy of the two great Universities of Oxford and Cambridge, and had fully justified the foresight of those who founded it. Time would make it as venerable as its rivals, and the generosity of public and private benefactors would soon enable the University to have buildings as beautiful and as well placed as any in the land.

The Chancellor, in reply, commented on the happy spirit of co-operation and goodwill which to-day existed between the learned institutions of the world. The exchange of teachers and students and ideas was of the utmost significance, and the Universities of the world might well claim that they were making a contribution of high value and importance in the promotion of peace and understanding. He stressed also the importance of unity, though not necessarily uniformity, within the University itself, and remarked on the analogy which the constitution of the University, with its federation of semi-autonomous Schools, presented to the British Empire. The one was no less real than the other. "The respective spheres of University and College", he said, "are clearly defined in black and white but no written statute is of any avail apart from that spirit of goodwill, that desire to pull together, which is characteristic of London University". The toast of "The Guests" was proposed by the Vice-Chancellor, Mr. H. L. Eason, who said : "This great gathering is a token that the ideal that should underlie all Universities is not forgotten, namely, that academic learning should have no boundaries of space, nation. ality, religion or politics. Without this spirit, learning would have perished in the Middle Ages, and there never was a period in the world's history when the maintenance of complete academic freedom of thought was more urgently needed than to-day". Prof. Louis Cazamian, of the University of Paris, Mr. G. H. Wilson, vice-chancellor of the University of Cambridge, Prof. L. P. Eisenhart, of Princeton University and Sir James Barrett, Chancellor of the University of Melbourne, responded, and congratulated the University on the distinguished record of its first hundred years.

Tuesday, June 30, was devoted mainly to functions at the various Colleges, while in the evening the Worshipful Company of Drapers, old and generous friends of the University, gave a ball at the Drapers' Hall.

On Wednesday, July 1, the University's friendly relations with the City of London were once more demonstrated and reaffirmed. To the special service of thanksgiving at St. Paul's Cathedral came a vast congregation of members and friends of the University. The citizens of London gazed upon a striking and colourful scene as the processions in academic costume wound up Ludgate Hill. First the professors and readers entered the Cathedral. Then came the Lord Mayor, the Sheriffs and Corporation; and finally the Chancellor's procession, consisting of the delegates from sister universities and learned bodies, honorary graduates, the Court and Senate and the Chancellor. The service, which was broadcast, was impressive in its simplicity. The Archbishop of Canterbury, in an eloquent sermon, paid tribute to the high ideal which had animated the founders of the University one hundred years ago and which was still incorporated in the Statutes, "to hold forth to all classes and denominations without any distinction whatsoever an encouragement for pursuing a regular and liberal course of education". This ideal was now accepted as a commonplace of public policy, but in those days great courage was needed to assert it. The University had been a pioneer of the movement which had given universities to most of our large cities, and though unlike its younger sisters it had not been able, by reason of the vastness of London, to make such an impact on the life of the city, the presence of an institution which not only prepared students for profitable and useful careers but which also fostered the things of the mind and the spirit, the pursuit of knowledge and truth for their own sake, was of incalculable benefit to London. Through. out its development the University had lacked one thing - a body, so to speak, in which its soul might find a fitting home. This was now at last to be remedied, and at Bloomsbury there was arising a great building wherein for the first time the length 
and breadth and depth and height of the ideals for which the University stood would find a visible, noble, enduring embodiment and witness-a reminder to London that it had its own University in its midst.

After the service, the Lord Mayor and Corporation gave a luncheon in Guildhall. Lord Halifax, speaking as Chancellor of the University of Oxford, said that one of the greatest achievements of the nineteenth century was the assertion of the principle of an extended university education. This had inevitably given rise to a tendency to consider that the progress of the human race was automatic, provided that education could be sufficiently widely diffused. It was, however, being increasingly realized in these days that much knowledge might be a dangerous and destructive thing unless it was directed by something greater than itself. One had only to think of man's discovery of aeroplanes, of chemical laws and products and even of the internal combustion engine, to realize how dangerous they could be, unless guided and inspired by that which was greater than themselves-wisdom. Civilization must depend on training men to become masters rather than victims of their own inventions. No greater aim could be set before a university, and they could wish no better thing for London's university than that for the next critical century of its history it might continue to inculcate those principles to which in the past hundred years it had been so faithful.

The Chancellor, in reply, said that the first and perhaps the most difficult stage of the University's history was now past, and they might recall, with justifiable elation, the apprehension and dismay with which at the outset the project was greeted. All that the University had striven and was striving for would be consolidated in its new home, and there the University would pursue its course, going quietly and steadily forward; and when the next hundred years had passed there would be found the same spirit, the same high ideals, which animated the University of London to-day.

Lord Macmillan, chairman of the University Court, who proposed the toast of "The Lord Mayor and Corporation", referred to the friendly relationship between 'town and gown' which had always existed in London, and recalled episodes separated in time by more than a hundred years in which the City Corporation had shown its great interest in the cause of university education in London. The University, like the City, was engaged in commerce - not of commodities but of ideas-a commerce which knew no quotas, no embargoes, but where universal free trade existed. The best means for bringing about in the distraught world a renewal of friendship, mutual confidence and well-being, was by the promotion of those common bonds which scholarship and learning alone could furnish. The Lord Mayor, responding, said that the Corporation of London had always identified itself with the cause of education and had ever striven for that freedom of thought and action, in the wise and appreciative use of which the finest achievements of the human mind had become available for the benefit of mankind.

In the evening, His Majesty's Government held a reception at Lancaster House, where the guests were received by the Lord President of the Council and Miss MacDonald.

The proceedings were brought to a conclusion on Friday, July 3 , with a brilliant reception given by the London County Council, the hospitality of which once more bore witness to the generosity and goodwill which characterizes its relationship with the University.

Throughout the week, hospitality was freely extended to the delegates by the Colleges and Schools of the University in the form of luncheons, garden parties, dinners and evening receptions, and all offered facilities for the visitors to see something of their work and activities.

A memorable occasion was thus worthily celebrated. The University, on the threshold of a new phase of its existence, may well be satisfied with the demonstrations of loyalty and friendship which the completion of its first hundred years has evoked, not only from those within its bounds but also from all those far and near who come into contact with its widespread activities.

\section{The National Physical Laboratory}

\section{Annual Inspection}

\begin{abstract}
$\mathrm{O}$ July 1, the annual inspection of the work in progress at the National Physical Laboratory was made by the General Board and also by a large number of visitors representative of scientific, academic and commercial institutions throughout the country. The visitors were received in the High Voltage Laboratory by Sir William Bragg, president of the Royal Society and chairman of the Board, the Right Hon. Lord Rayleigh, chairman of the Executive Committee, and Sir Frank Smith, director of the Laboratory. Some three hundred exhibits illustrating the work performed in the eight departments of the Laboratory were on view; a brief summary of some of the more recent or interesting developments is given below.
\end{abstract}

In the Physics Department, the analogous problems of the transfer of heat from metal pipes and moisture from wet surfaces to a stream of air flowing over them have been investigated, and similar laws are found to hold for the two processes. The effect of inducing turbulence in the air-stream has also been studied. A simple falling plug method for determining the viscosities of liquid refrigerants has been devised. The apparatus is calibrated with liquids of known viscosity, and may easily be adapted to work under pressure and at low temperatures. The investigation of the changes of length of hygroscopic materials with humidity has continued and a demonstration was given of the application of such a material-gold beaters' skin - to the maintenance 